\title{
Analisis Kebisingan Arus Lalu Lintas terhadap Kegiatan Belajar Mengajar (KBM) di SMA Swasta Surabaya
}

\author{
Susilo Indrawati, ${ }^{*}$ Beta Bayu Santika, dan Suyatno \\ Jurusan Fisika- FMIPA, Institut Teknologi Sepuluh Nopember, Kampus ITS Sukolilo, Surabaya 60111
}

\begin{abstract}
Intisari
Kebisingan yang terjadi di kehidupan sehari-hari umumnya berasal dari industri, transportasi. Dewasa ini, jalan raya adalah sumber utama kebisingan. Kebisingan dari jalan raya memiliki dampak yang menyeluruh, sementara yang lain hanya bersifat lokal yang artinya hanya pada daerah-daerah tertentu. Aktivitas manusia baik di luar maupun di dalam bangunan pada area yang berdekatan dengan jalan raya, sangatlah potensial menjadi korban kebisingan. Kebisingan akan berakibat menurunnya mendengar dan turunnya konsentrasi belajar pada anak. Sekolah khadijah merupakan salah satu sekolah yang sangat terganggu dengan adanya kebisingan arus lalu lintas. Letak sekolah yang langsung berhadapan dengan jalan raya sangat menimbulkan kebisingan. Hasil pengukuran tingkat tekanan bunyi (SPL) kebisingan yang diakibatkan arus lalu lintas mencapai $87 \mathrm{~dB}$. Besarnya NC (Noise critera) diarea parkir sekolah mencapai $78 \mathrm{~dB}$, sedangkan di area dalam sekolah nilai NC mencapai $70 \mathrm{~dB}$. Menurut baku tingkat kebisingan untuk sekolah adalah $55 \mathrm{~dB}$. Berdasarkan analisis nilai noice reduction $(\mathrm{NR})$ pada muka dinding ruang kelas diperoleh cukup bagus, tapi perlu untuk melakukan beberapa perbaikan, pertama adalah pemberian bahan isolasi di lorong/ depan yang berhubungan langsung dengan sumber kebisingan. Perbaikan yang kedua adalah dengan perbaikan pada engsel pintu dan celah jendela yang cukup besar.
\end{abstract}

\begin{abstract}
Noise we experience daily is mainly caused by industry, train, plane, and traffic activity. Nowadays, traffic is the main cause for noise, because the noise caused by traffic have systemic cause, meanwhile other source of noise are rather local. Anyone that has activity whether outside or inside a building near a traffic dense road will be affected by the noise. Noise will affect to the deteriorating of the hearing and child concentration. Khadijah school is one of the school that is heavily affected by traffic noise. The school locates near a heavy traffic road, which caused a lot of noise. From the sound pressure level (SPL), the noise caused by the traffic reached $87 \mathrm{~dB}$. The noise criteria (NC) in the parking area of the school reachs $78 \mathrm{~dB}$, while inside the school the NC reach $70 \mathrm{~dB}$. While according to some research and regulation, the NC in school area should be around $55 \mathrm{~dB}$. By analyzing the fade of the classroom wall, its found that the wall have great noise reduction. The fade is made from double wood door with $3 \mathrm{~cm}$ thickness, $3 \mathrm{~mm}$ glass windows, and brick wall with $10 \mathrm{~cm}$ thickness. The material used in the building are up to standard, but it need some adjustment. The first adjustment should be adding an insulation material on the hallway that connected directly to the noise source the second adjustment should be minimalizing the gap in the door and windows by using a rubber so that the noise could not pass through the gap.
\end{abstract}

KATA KUNCI: traffic noise, school, noise criteria http://dx.doi.org/10.12962/j24604682.v13i1.2131

\section{PENDAHULUAN}

Persoalan kebisingan di negara berkembang, seperti Indonesia, seringkali lebih rumit apabila dibandingkan dengan yang dihadapi oleh negara maju. Di negara berkembang, dengan tingkat pendidikan dan ekonomi masyarakatnya yang masih rendah, orang cenderung mengabaikan permasalahan kebisingan. Beberapa alasan yang mendasari sikap ini diantaranya adalah, belum adanya informasi yang jelas mengenai akibat buruk kebisingan bagi kenyamanan dan kesehatan

*E-MAIL: susilo.indra.its@gmail.com manusia. Anggapan lain dari kebisingan, bahwa solusi untuk mengatasi kebisingan selalu rumit dan memerlukan biaya yang mahal. Sementara itu, perkembangan yang terjadi menunjukkan bahwa kebisingan yang dihasilkan kendaraan bermotor pada di jalan-jalan terus meningkat dan semakin parah. Menurut Psikolog Rosidah [1] kebisingan akan berakibat menurunnya mendengar dan turunnya konsentrasi belajar pada anak. Sekolah Khadijah merupakan salah satu sekolah yang sangat terganggu dengan adanya kebisingan arus lalu lintas.

Hasil penelitian Ikron $d k k$. (2007) [2] menunjukkan bahwa resiko anak SD yang menerima kebisingan $>61,8 \mathrm{dBA}$ Leq berisiko 10,8 kali mengalami gangguan kesehatan psikologis dibandingkan dengan anak SD yang menerima kebisingan $>$ 


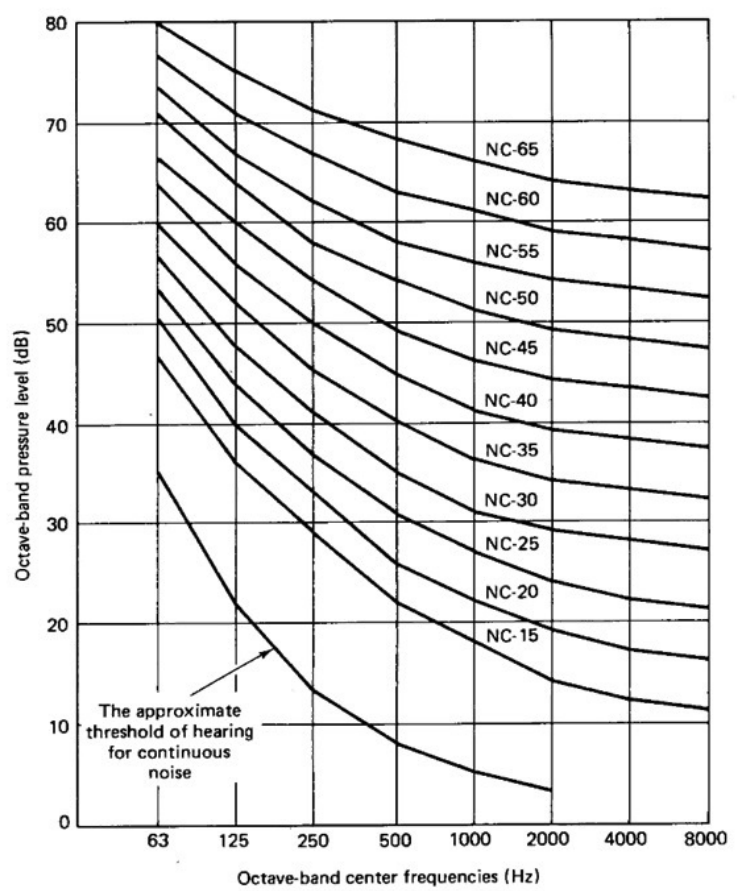

Gambar 1: Kurva noise criteria [3].

61,8 dBA Leq. Hal ini menunjukkan bahwa dampak kebisingan sangat berpengaruh terhadap psikologis, yang nantinya berkaitan dengan daya konsentrasi anak.

Kebisingan dikatakan nyaman apabila berada pada tingkat kekerasan yang tidak melebihi $40 \mathrm{~dB}$. Selain ditentukan oleh tingkat kebisingan (dB), tingkat gangguan kebisingan juga ditentukan oleh frekuensi bunyi yang muncul. Oleh karenanya, kedua faktor itu kemudian dipertimbangkan bersama dalam sebuah pengukuran yang disebut Noise Criteria (NC). Sebagaimana ditunjukkan pada Gambar 1, semua kurva menunjukkan tingkat ketegangan telinga manusia pada bunyi multifrekuensi yang menjadi noise latar belakang. Selain itu, dari gambar tersebut dapat dipelajari bahwa meski setiap kurva mewakili nilai NC tertentu, namun pada frekuensi tinggi secara umum nilai SPL-nya rendah atau menurun. Hal ini menunjukkan bahwa telinga manusia lebih nyaman (tidak merasa sakit) mendengar bunyi berfrekuensi rendah daripada bunyi berfrekuensi tinggi [3].

Kebisingan yang mengganggu lingkungan habitat manusia dapat memberikan dampak yang merugikan manusia itu sendiri, baik secara fisiologis maupun psikologis. Pengaruh kebisingan terhadap manusia tergantung pada karakter fisis, waktu berlangsung dan waktu kejadiannya. Bentuk gangguan yang diakibatkan kebisingan antara lain pendengaran dan gangguan percakapan [4]. Keputusan menteri Negara lingkungan hidup No 32 Kep-48/MENLH/11/1996, tentang baku tingkat kebisinga menyebutkan: kebisingan adalah bunyi yang tidak diinginkan dari usaha atau kegiatan dalam tingkat dan waktu tertentu yang dapat menimbulkan gangguan kesehatan manusia dan kenyamanan lingkungan. Baku tingkat kebisingan ditunjukkan Tabel I [5].
TABEL I: Baku Tingkat Kebisingan.

$\overline{\overline{\text { P eruntukan Kawasan/Lingkungan Kesehatan }} \text { Tingkat Kebisingan }}$ (dBA)

Pe- runtukan kawasan

a. Perumahan dan pemukiman $\quad 55$

b. Perdagangan dan jasa $\quad 70$

c. Perkantoran dan perdagangan 65

d. Ruang terbuka hijau $\quad 50$

e. Industri 70

f. Pemerintahan dan fasum 60

$\begin{array}{ll}\text { g. Rekreasi } & 70\end{array}$

Li- ngkup kegiatan

a Rumah sakit atau sejenisnya 55

b Sekolah atau sejenisnya $\quad 55$

c Tempat Ibadah atau sejenisnya $\quad 55$

Sumber: Menteri Negara Lingkungan

Hidup, 1996

Salah satu tempat yang harus terbebas dari kebisingan adalah sekolah. Lingkungan pendidikan yang terbangun dalam sebuah bangunan sekolah dapat berperan dalam peningkatan mutu pembelajaran. Dalam dunia pendidikan, lingkungan yang tenang dan nyaman sangat dibutuhkan dalam proses belajar mengajar. Sebab konsentrasi siswa dalam menerima materi pelajaran juga turut dipengaruhi oleh lingkungannya. Apabila dalam lingkungan belajar siswa terjadi sebuah ketidaknyamanan, maka konsentrasi yang dimiliki siswa-pun akan terganggu. Materi pelajaran yang diterima siswa menjadi tidak dapat diserap seutuhnya, sehingga hal ini dapat berpengaruh pada hasil belajar siswa terhadap pelajaran tersebut. Hal ini dialami salah satu bangunan sekolah swasta di Surabaya, sekolah yang letaknya dekat dengan jalan raya dan persimpangan kereta api Wonokromo yang berdekatan dengan pasar dan arus lalu lintas yang sangat padat.

\section{METODOLOGI PENELITIAN}

\section{Observasi Awal dan Persiapan}

Observasi awal adalah sebuah tahapan dalam menentukan desain titik pengukuran dengan cara melakukan pengamatan langsung kondisi objek penelitian. Objek yang diamati yaitu Sekolah SMA Swasta Surabaya, serta mengumpulkan faktorfaktor yang memengaruhi kebisingan yang diterimanya. Dari proses observasi awal ini kemudian akan dilakukan pembuatan desain titik pengukuran, yaitu titik-titik pengambilan data selama pengukuran. Perangkat lunak yang digunakan yang digunakan adalah YMEC sound measurement software fullsystem, yang terdiri dari 3 program yaitu Realtime Analyzer; Sound Analyzer dan Environmental Noise Analizer. Dengan penggunaan program tersebut dapat dilakukan pengukuran secara realtime dan dapat di simpan secara otomatis. Pada tahap observasi ini hanya dilakukan pengukuran noise criteria di lingkungan sekolah. Adapun area yang dilakukan pengukuran yaitu jalan raya, tempat parkir, taman, dan di depan kelas. 


\section{Pengukuran}

Pada penelitian ini, pengukuran yang dilakukan mempunyai beberapa sasaran yaitu mengetahui distribusi kebisingan di sekitar kelas (atenuasi bunyi), mengetahui nilai noise criteria di dalam ruang kelas (diambil 1 sampel kelas yang dianggap sebagai mewakili kelas yang lain), mengetahui aspek kebocoran pada dinding muka ruang kelas.

\section{Pengambilan tingkat tekanan bunyi sekitar kelas}

Pada tahap ini dilakukan pengukuran seberapa besar tingkat tekanan bunyi ketika berada di luar kelas, sebelumya telah dilakukan pengukuran tingkat tekanan bunyi di area luar Sekolah hal ini dirasa perlu apakah ada efek atenuasi karena jarak ataukah mungkin ada perbedaan tingkat tekanan bunyi yang cukup signifikan.

\section{Pengambilan data Noise Criteria (NC)}

Pada pengukuran ini akan diambil sampel yaitu kelas 12 . Ruangan ini merupakan ruangan yang paling bising jika dibandingkan dengan ruang kelas lainnya selain letaknya yang berada di lantai 2, kelas ini juga langsung menghadap jalan raya yang juga bersebelahan dengan pusat perbelanjaan. Pengukuran ini dilakukan pada saat aktivitas sekolah berlangsung, hal ini diharapkan agar pegukuran yang dilakukan memang merupakan kondisi riil ketika aktivitas berlangsung.

Pengukuran noise criteria ini posisi ketinggian SLM diatur setinggi telinga manusia pada saat duduk yaitu $120 \mathrm{~cm}$. ketinggian ini berbeda karena ketika di dalam kelas posisi siswa ketika pelajaran berlangsung adalah dalam posisi duduk.

\section{Pengambilan data distribusi SPL di dalam kelas}

Pengukuran ini juga menggunakan peralatan yang sama yaitu menggunakan sound level meter. Untuk mengetahui persebaran dalam kelas, perlu dilakukan pengukuran distribusi SPL. Pengukuran ini menggunakan enam titik ukur dengan posisi seperti ditunjukkan pada denah Gambar 2.

\section{HASIL DAN PEMBAHASAN}

\section{Tingkat tekanan bunyi di area sekitar kelas}

Pengukuran tingkat tekanan bunyi selanjutnya akan dilakukan di area kelas yang menjadi sampel yaitu di area kelas 12 yang berada di lantai 2 dekat dengan jalan raya. Dari hasil pengukuran tingkat tekanan bunyi sekitar / background noise dapat dilihat pada Tabel II.

Berdasarkan hasil yang diperoleh dapat disimpulkan bahwa area di sekitar kelas tersebut masih terdengar bising. Hal ini dikarenakan oleh tempat yang masih belum terisolasi oleh bunyi, masih ada lubang angin-angin yang sangat besar sehingga tidak dapat mengurangi kebisingan.

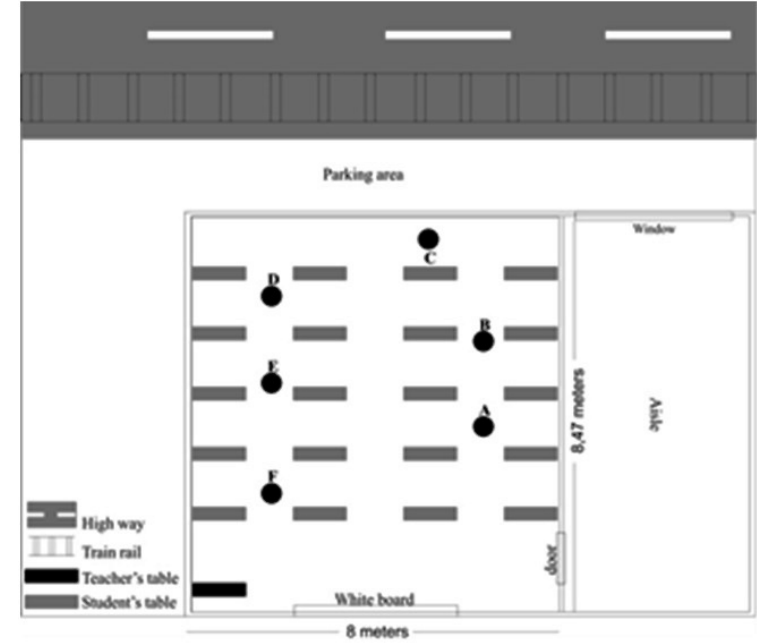

Gambar 2: Denah titik ukur pengambilan distribusi SPL dalam Kelas.

TABEL II: Data background noise sekitar kelas 12.

\begin{tabular}{cc}
\hline $\begin{array}{c}\text { Frekuensi } \\
(\mathrm{Hz})\end{array}$ & $\begin{array}{c}\text { Background Noise } \\
(\mathrm{dBA})\end{array}$ \\
\hline & \\
all & 78.3 \\
63 & 49.2 \\
125 & 59.1 \\
250 & 61.0 \\
500 & 63.4 \\
1000 & 66.6 \\
2000 & 64.3 \\
4000 & 57.2 \\
5000 & 54.3 \\
\hline \hline
\end{tabular}

\section{Pengukuran noise criteria (NC)}

Pengukuran yang selanjutnya untuk mengetahui pengaruh kebisingan terhadap sekolah adalah dengan mengukur besarnya noise criteria di dalam kelas tersebut. Waktu pengukuran yang diambil adalah pada waktu kegiatan/ aktivitas berlangsung yaitu berkisar antara jam 9-11 siang, dengan hasil pengukuran ditunjukkan Gambar 3.

Mengacu pada kurva Gambar 1 kurva NC, dilakukan ploting data dengan menggunakan 6 titik ukur seperti dijelaskan pada Gambar 2. Data yang ditunjukkan Gambar 3 diperoleh data NC 58-64. Hal ini menunjukkan masih jauh dibandingkan dengan nilai NC yang direkomendasikan. Dari data yang diperoleh diperlukan perbaikan akustik ruang di ruang kelas tersebut sehingga dapat menurunkan kebisingan.

\section{Pengambilan data distribusi SPL dalam ruang kelas}

Pengukuran ini dilakukan untuk mengetahui pola persebaran bunyi di dalam ruang, dan dilakukan pada 6 titik ukur. Ketinggian alat ukur (microphone) adalah $120 \mathrm{~cm}$, disesuaikan dengan ketinggian telinga ketika siswa duduk. Hasil pengukuran tingkat tekanan di dalam ruang dapat disajikan dalam bentuk kontur seperti ditunjuukan pada Gambar 4. 


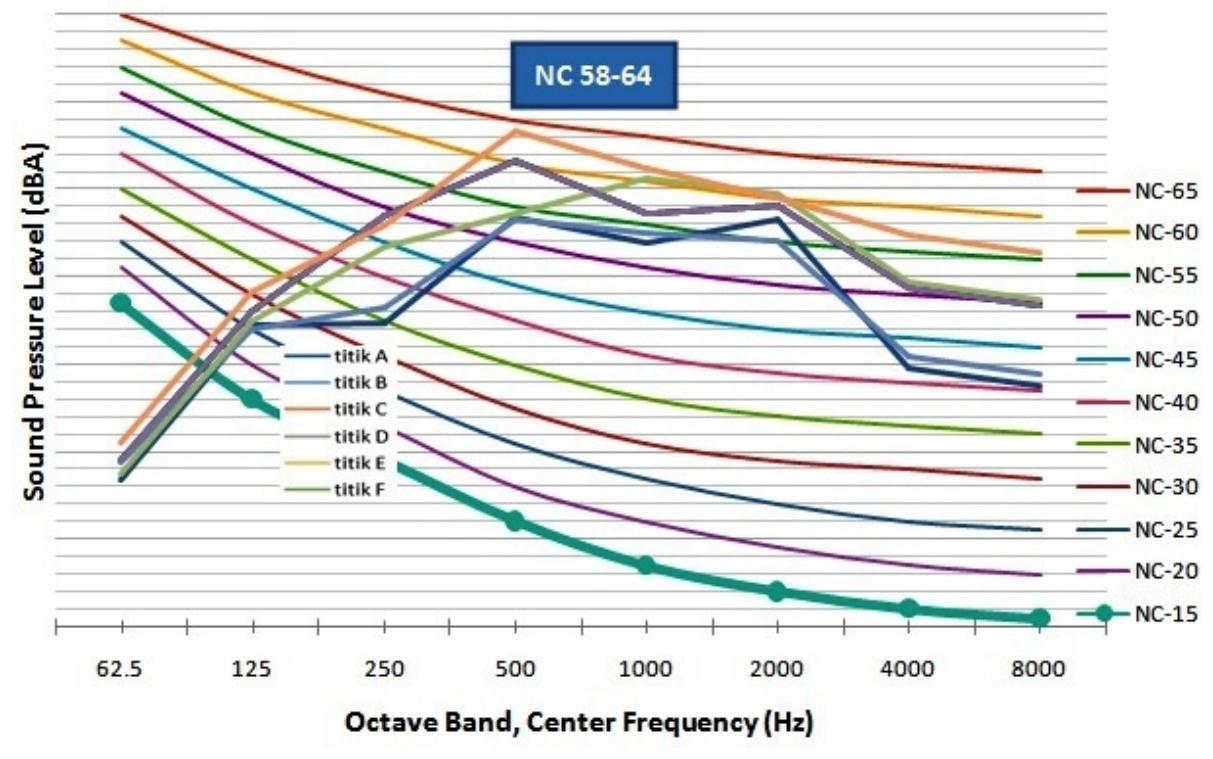

Gambar 3: Grafik pengukuran Noise Criteria kelas 12 lantai 2 SMA Swasta Surabaya.

TABEL III: Nilai Noise Reduksi.

\begin{tabular}{lcccccc}
\hline \hline & \multicolumn{7}{c}{$\mathrm{N}$ i 1 a i } & NR & $(\mathrm{dBA})$ \\
& $125 \mathrm{~Hz}$ & $250 \mathrm{~Hz}$ & $500 \mathrm{~Hz}$ & $1 \mathrm{kHz}$ & $2 \mathrm{kHz}$ & $4 \mathrm{kHz}$ \\
\hline \multirow{3}{*}{ Celah jendela } & 10,0 & 3,7 & 0,3 & 2,1 & 2,7 & 4,2 \\
jendela & 6,8 & 9,3 & 4,7 & 8,6 & 9,4 & 14 \\
tembok & 5,7 & 11 & 5,2 & 7,3 & 9 & 13,4 \\
Celah pintu & 2,6 & 1,9 & 2,8 & 1,0 & 3,6 & 3,5 \\
pintu & 5,2 & 7,4 & 6,9 & 9,7 & 9,6 & 11,7 \\
\hline \hline
\end{tabular}

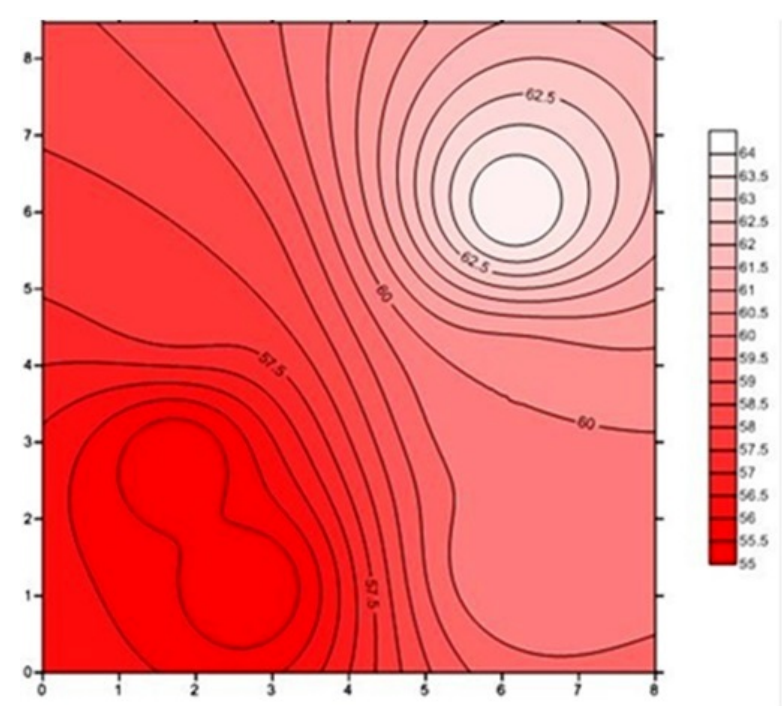

Gambar 4: Gambar kontur distribusi SPL di dalam kelas

Pada Gambar 4, warna pada gambar semakin gelap menandakan bahwa distribusi SPL semakin rendah. Terlihat dari gambar bahwa distribusi SPL yang diperoleh memiliki selisih 10 dBA, hal ini menunjukkan bahwa nilai tersebut dis- tribusi yang tidak merata oleh sebab itu orang yang ada di depan dibandingkan dengan yang dibelakang memiliki perbedaan yang jauh. Pada Gambar 4 menunjukkan bahwa ruang yang mengalami kebisingan yaitu di daerah warna cerah, artinya daerah-daerah tersebut diperlukan material yang mampu meredam kebisingan. Material penyusun di ruang kelas terbuat dari batu bata, terkecuali dengan pintu dan jendela. Pintu yang digunakan di kelas tersebut sudah bagus berupa dua pintu yang terbuat dari kayu dengan ketebalan 3 $\mathrm{cm}$ dan kaca ketebalan $3 \mathrm{~mm}$. Jendela yang dipakai di kelas ini terbuat dari kaca dengan ketebalan $3 \mathrm{~mm}$. Dilihat dari komponen penyusun pada ruang kelas seharusnya ruang sudah cukup bagus dalam menangani kebisingan. Hasil pengukuran noise reduksi (NR) pada bagian- bagian penyusun bangunan ditunjukkan pada Tabel III. Noise reduksi merupakan hasil pengurangan antara SPL kebisingan sebelum dan sesudah melewati panel. Data yang diperoleh dari pengukuran diperoleh nilai NR yang kecil. Nilai NR yang kecil menunjukkan bahwa kemampuan dalam mentransmisikan bunyi sangat rendah. Nilai NR ini redah dikarenakan pada pemasangan pintu, engsel pada jendela kurang rapat sehingga bunyi bisa menembus celah sehingga kebisingan masih terasa di dalam kelas. 


\section{Ucapan Terima Kasih}

Penulis mengucapkan terima kasih kepada LPPM-ITS (Lembaga Penelitian Dan Pengabdian masyarakat) dan BOPTN dengan no kontrak 31460/IT2.11/PN.08/2016 atas dukungan dana sehingga pekerjaan ini dapat dilakukan.

\section{SIMPULAN}

Berdasarkan hasil analisis data maka dapat disimpulkan:
- Besanya tingkat tekanan bunyi di jalan lalu lintas $=87$ $\mathrm{dB}$

- Besarnya NC di dalam kelas berkisar antara 58-64

- Material yang digunakan dalam bahan bangunan (kelas) cukup baik namun dalam pemasangan perlu adanya perbaikan khususnya dalam pemasangan. Perlu diberi karet untuk menutupi celah pada pintu dan jendela.
[1] Rosidah, Studi Kejadian Hipertensi Akibat Bising Pada Wanita yang tinggal di Sekitar Lintasan Kereta Api di Kota Semarang, Tesis, Magister Kesehatan Lingkunngan Program Pasca Sarjana Universitas Diponegoro Semarang, 2004.

[2] Ikron, dkk., Pengaruh kebisingan lalu lintas terhadap gangguan kesehatan psikologis anak SDN Cipinong Muara kecamatan. Jatinegara, kota Jakarta Timur Propinsi DKI Jakarta, Makara,
Kesehatan, 11(1), FKM Universitas UI, (2007).

[3] L.L. Beranek, Acoustic (Amer Inst of Physics, 1960).

[4] D.P. Sasongko, H. Agus, Kebisingan lingkungan (Badan penerbit UNDIP Semarang, 2000).

[5] Keputusan Menteri Lingkungan Hidup Nomor: 48/ MENLAH/11/1996 tahun 1996. 